\title{
MINAT MENJADI GURU TEKNIK PADA MAHASISWA NON REGULER
}

\author{
Wisnu Y. Nugroho', Tatang Permana ${ }^{2}$, Mumu Komaro ${ }^{3}$ \\ Universitas Pendidikan Indonesia \\ Jl. Dr. Setiabudi No. 229 Bandung 40154 \\ wisnuyola66@gmail.com
}

\begin{abstract}
ABSTRAK
Penelitian ini bertujuan untuk mengetahui besarnya minat mahasiswa kerjasama Pemerintah Sumatera Selatan dengan UPI untuk menjadi guru teknik dan mengetahui faktor yang menyebabkan mahasiswa kerjasama Pemerintah Provinsi Sumatera Selatan dengan UPI berminat dan tidak berminat menjadi guru teknik. Penelitian ini menggunakan metode deskriptif dengan pendekatan kuantitatif dan teknik pengumpulan data melalui angket. Populasi dalam penelitian ini adalah mahasiswa FPTK kerjasama Pemerintah Sumatera Selatan dengan UPI dan teknik pengambilan sampel menggunakan metode purposive sampling. Berdasarkan hasil penelitian diperoleh bahwa 1) Mahasiswa kerjasama Pemerintah Provinsi Sumatera Selatan dengan UPI, lebih dari setengahnya berminat menjadi guru teknik. 2) Mahasiswa kerjasama Pemerintah Provinsi Sumatera Selatan dengan UPI yang berminat menjadi guru teknik, penyebab utamanya adalah faktor internal dan penyebab lainnya adalah faktor eksternal. 3) Mahasiswa kerjasama Pemerintah Provinsi Sumatera Selatan dengan UPI yang tidak berminat menjadi guru teknik. Faktor penyebab utamanya adalah faktor internal dan penyebab lainnya adalah faktor eksternal.
\end{abstract}

Kata kunci: minat, guru teknik, kejuruan,

\section{PENDAHULUAN}

Sumatera Selatan adalah salah satu Provinsi di Indonesia yang membutuhkan tenaga guru profesional terutama guru produktif di SMK. Berdasarkan data BPSDMPK-PMP, Sumatera Selatan berada di urutan kelima dalam hal provinsi yang sangat membutuhkan tenaga guru profesional. Untuk mengatasai hal tersebut, mulai tahun 2011, Dinas Pendidikan Provinsi Sumatera Selatan yang didukung oleh Dinas Pendidikan Kabupaten bekerjasama dengan UPI. Program kerjasama Pemerintah Provinsi Sumatera Selatan dengan UPI disebut program kerjasama beasiswa kemitraan daerah.

Program beasiswa kemitraan Provinsi Sumatera Selatan dengan UPI bertujuan menghasilkan calon guru yang berkualitas untuk memenuhi kebutuhan akan guru Sekolah Menengah Pertama (SMK) yang saat ini masih kekurangan. Mahasiswa kerjasama Pemerintah Sumatera Selatan dengan UPI digolongkan menjadi mahasiswa non regular (Trianto, 2012).

Data diketahui sampai awal tahun 2017, sebanyak 34 mahasiswa kerjasama telah menyelesaikan pendidikan S1 di UPI. Sedangkan sebanyak 92 mahasiswa masih berstatus mahasiswa aktif dan masih menempuh pendidikan di UPI. Lebih lanjut, dari 92 mahasiswa

\footnotetext{
${ }^{1}$ Mahasiswa Departemen Pendidikan Teknik Mesin FPTK UPI

2 Dosen Departemen Pendidikan Teknik Mesin FPTK UPI

${ }^{3}$ Dosen Departemen Pendidikan Teknik Mesin FPTK UPI
} 
yang masih menempuh pendidikan di UPI, sebanyak 65 mahasiswa berada di FPTK, 21 mahasiswa di FPMIPA dan 6 mahasiswa di FPEB.

Wawancara awal peneliti dengan lima belas mahasiswa kerjasama Pemerintah Provinsi Sumatera Selatan yang masih berstatus mahasiswa aktif di FPTK UPI, terdapat 10 orang mahasiswa (67\%) yang berminat menjadi guru. Sedangkan 5 orang mahasiswa (33\%) menyatakan tidak berminat menjadi guru dan memilih profesi lain selain menjadi guru. Mahasiswa kerjasama Pemerintah Sumatera Selatan dengan UPI yang tidak berminat menjadi guru. Hal ini tentu tidak sesuai dengan tujuan FPTK UPI yaitu untuk mendidik tenaga kependidikan teknologi dan kejuruan untuk menghasilkan Sarjana Pendidikan Teknologi dan Kejuruan (guru, ahli pendidikan, dan tenaga kependidikan teknologi lainnya) secara professional (Usman, 2005). Hal ini juga tidak sejalan dengan tujuan program beasiswa kemitraan daerah provinsi Sumatera Selatan yang mewajibkan mahasiswa kerjasama untuk menjadi tenaga pendidik di daerah asal ketika telah lulus dari UPI. Sumatera Selatan akan kekurangan guru produktif, apabila hal ini terus terjadi dalam jangka panjang. Beasiswa kerjasama pemerintah Sumatera Selatan tidak sesuai dengan tujuan. Penelitian ini bertujuan untuk mengetahui besarnya minat mahasiswa non reguler FPTK UPI untuk menjadi guru teknik, mengetahui faktor yang menyebabkan mahasiswa non reguler FPTK UPI berminat menjadi guru teknik, dan mengetahui faktor yang menyebabkan mahasiswa non reguler FPTK UPI tidak berminat menjadi guru teknik.

\section{METODE PENELITIAN}

Penelitian ini menggunakan metode deskriptif dengan pendekatan kuantitatif. Metode deskriptif digunakan untuk menggambarkan masalah yang terjadi pada masa sekarang atau yang sedang berlangsung. Penelitian ini merupakan penelitian yang mendeskripsikan suatu gejala atau fenomena yang terjadi pada mahasiswa non reguler FPTK UPI. Pendekatan kuantitatif adalah pendekatan yang digunakan dalam penelitian dengan cara mengukur indikator pada variabel penelitian. Penggunaan metode deskriptif kuantitatif ini diselaraskan dengan variabel penelitian yang memusatkan pada masalah yang aktual dan fenomena yang sedang terjadi pada saat sekarang.

Penelitian ini dilaksanakan di Fakultas Pendidikan Teknologi dan Kejuruan (FPTK). Sasarannya yaitu mahasiswa kerjasama pemerintah Sumatera Selatan dengan UPI di FPTK. Penelitian ini difokuskan terhadap minat menjadi guru teknik pada mahasiswa. Populasi pada penelitian ini adalah mahasiswa FPTK kerjasama Pemerintah Sumatera Selatan dengan 
UPI yang berjumlah 63 mahasiswa. Pemilihan populasi ini merupakan objek dalam peneltian ini.

Instrumen penelitian yang digunakan adalah angket. Hasil dari analisa data untuk mengetahui minat mahasiswa non reguler FPTK UPI untuk menjadi guru teknik pada penelitian ini adalah berupa prosentase. Pengolahan data dalam penelitian ini menggunakan statistik analisis faktor dengan analisis faktor menggunakan Software SPSS 16.0. Analisis faktor digunakan untuk mencari faktor dominan yang menyebabkan mahasiswa non reguler FPTK UPI berminat/tidak berminat menjadi guru teknik.

\section{HASIL PENELITIAN}

Data penelitian menunjukkan persentase minat mahasiswa kerjasama pemerintah Provinsi Sumatera Selatan dengan UPI menjadi guru teknik yaitu sebesar 73,4\%, sedangkan sebanyak 26,6\% tidak berminat menjadi guru teknik. Mahasiswa kerjasama pemerintah rovinsi Sumatera Selatan dengan UPI sebagian besar berminat menjadi guru teknik.

Faktor yang menyebabkan mahasiswa non reguler FPTK UPI berminat menjadi guru teknik ditunjukkan dari nilai extraction dan penafsiran data penelitian. Faktor internal yaitu keinginan diri sendiri tanpa paksaan sebesar 79,4\% termasuk besar. Faktor eksternal meliputi lingkungan belajar adalah 74,5\%, masuk dalam kategori cukup besar. Faktor beasiswa kemitraan yaitu sebesar $68,6 \%$, masuk dalam kategori besar. Faktor lingkungan tempat tinggal sebesar 50,6\%, masuk ke dalam kategori besar. Faktor posisi dan lingkungan dalam keluarga sebesar 48,7\%, masuk ke dalam kategori besar. Hasil tersebut menunjukkan bahwa faktor yang paling dominan menyebabkan mahasiswa non reguler FPTK UPI berminat menjadi guru teknik adalah faktor internal yaitu keinginan diri sendiri tanpa paksaan.

Faktor internal dan faktor eksternal merupakan penyeebab mahasiswa non reguler FPTK UPI tidak berminat menjadi guru teknik. Nilai faktor-faktor yang menyebabkan mahasiswa non reguler FPTK UPI berminat menjadi guru teknik ditunjukkan dari nilai extraction dan penafsiran data penelitian. Nilai faktor internal yaitu keinginan diri sendiri tanpa paksaan sebesar 82,1\%. Faktor eksternal meliputi beasiswa kemitraan sebesar 79,2\%. Faktor posisi dan lingkungan dalam keluarga sebesar 71,7\%. Faktor lingkungan tempat tinggal sebesar 66,9\%. Faktor nilai lingkungan belajar sebesar 47,3\%. Hasil tersebut menunjukkan faktor yang paling dominan menyebabkan mahasiswa non reguler FPTK UPI tidak berminat menjadi guru teknik adalah faktor internal yaitu keinginan diri sendiri tanpa paksaan. 


\section{PEMBAHASAN}

Minat menjadi guru teknik adalah posisi pertama dari pemilihan minat pada mahasiswa kerjasama pemerintah Provinsi Sumatera Selatan dengan UPI dengan presentase $73,5 \%$. Minat yang dimiliki oleh seseorang dapat menjadi dasar atau landasan dalam melaksanakan suatu aktivitas, sehingga dapat diperoleh hasil yang maksimal. Minat berperan dalam mendorong seseorang untuk mencapai tujuannya (Rokhimah, 2015). Guru produktif merupakan tenaga professional yang bertugas di SMK untuk melaksanakan proses pembelajaran, menilai hasil pembelajaran, serta memberi teladan dan menjaga nama baik lembaga, profesi dan kedudukan sesuai dengan kepercayaan yang diberikan kepadanya. Profesi yang meliputi tenaga pembimbing, pengajar, tenaga pelatih, dan instruktur dalam bidang keahlian kejuruan.

Minat mahasiswa kerjasama pemerintah provinsi sumatera selatan dengan UPI menjadi guru teknik juga sesuai dengan Peraturan Daerah Provinsi Sumatera Selatan nomor 17 tahun 2010 tentang Tugas Belajar dan Beasiswa Pasal 13 Ayat 1, yaitu mahasiswa penerima beasiswa diwajibkan mengikuti kegiatan pendidikan sebagaimana mestinya sesuai ketentuan yang berlaku dan mengabdi kepada Pemerintah Provinsi sepanjang keahliannya diperlukan oleh Pemerintah Provinsi sesuai ketentuan yang berlaku.

Faktor internal adalah faktor dominan yang menyebabkan lebih dari setengah mahasiswa kerjasama pemerintah Provinsi Sumatera Selatan dengan UPI berminat menjadi guru teknik. Faktor internal yang dimaksud adalah berupa dorongan dari dalam individu yang berhubungan erat dengan dugaan dorongan fisik yang timbul secara alami dan tanpa paksaan orang lain ataupun pengaruh dari faktor sosial lainnya (Schiefele, 2005). Minat menjadi guru adalah ketertarikan seseorang terhadap profesi guru. Hal tersebut ditunjukkan dengan adanya pemusatan pikiran, perasaan senang, perhatian yang lebih terhadap profesi guru. Minat menjadi guru dapat diketahui dengan seringnya objek penelitian melakukan kegiatan yang berhubungan dengan profesi guru. Perasaan senang dan ketertarikan terhadap profesi guru, perhatian yang lebih besar terhadap profesi guru. Kemauan dan hasrat untuk menjadi guru, dan frekuensi melakukan kegiatan yang berhubungan dengan profesi dan kompetensi seorang guru profesional.

Selain faktor internal berupa keinginan diri mahasiswa yang memang tidak berminat menjadi guru teknik. Faktor eksternal merupakan salah satu faktor dominan yang menyebabkan kurang dari setengah mahasiswa kerjasama pemerintah Provinsi Sumatera Selatan dengan UPI tidak berminat menjadi guru teknik. Faktor eksternal tersebut meliputi beasiswa kemitraan sebesar 79,2\%. Artinya sebagian besar, posisi dan lingkungan dalam 
keluarga sebesar 71,7\% artinya lebih dari setengahnya, lingkungan tempat tinggal, sebesar $66,9 \%$ artinya lebih dari setengahnya, dan lingkungan belajar sebesar 47,3\% artinya kurang dari setengahnya.

Mahasiswa yang tidak berminat menjadi guru teknik dapat diketahui dari jarangnya melakukan kegiatan yang berhubungan dengan profesi dan kompetensi seorang guru professional. Perhatian yang kecil terhadap profesi guru, ketertarikan akan profesi selain guru, dan lain-lain. Mahasiswa kerjasama pemerintah Provinsi Sumatera Selatan dengan UPI tidak berminat menjadi guru teknik karena mahasiswa tersebut memiliki perhatian utama terhadap kegiatan lain. Misalnya lebih memilih bekerja di dunia industri daripada menjadi seorang guru. Adanya konflik pribadi dengan orang tua seperti dipaksa menjadi seorang guru, dan sebagainya.

Faktor eksternal yang menyebabkan mahasiswa kerjasama pemerintah Provinsi Sumatera Selatan dengan UPI tidak berminat menjadi guru teknik, yaitu faktor beasiswa, diikuti oleh faktor posisi dan lingkungan dalam keluarga, lingkungan tempat tinggal, dan lingkungan belajar. Minat mahasiswa kerjasama Pemerintah Provinsi Sumatera Selatan dengan UPI menjadi guru teknik tercermin dalam proses ketika mahasiswa melaksanakan Program Pengalaman Lapangan (PPL). Mahasiswa yang berminat menjadi guru teknik cenderung melaksanakan kegiatan yang berhubungan dengan kompetensi-kompetensi guru profesional. Hasil belajar mahasiswa ketika melaksanakan PPL dapat membentuk minat mahasiswa untuk menjadi guru teknik. Pengalaman yang didapatkan selama mahasiswa menempuh pendidikan di UPI khususnya pengalaman dari PPL sangat diperlukan dalam upaya mempersiapkan mahasiswa menjadi calon guru yang mampu melaksanakan tugastugas keguruan dengan baik (Sagala, 2011). Pengalaman kependidikan ini dapat meningkatkan kemampuan dan keterampilan mahasiswa terutama dalam bidang keahlian keguruan yang sesuai dengan kompetensinya, sehingga hasilnya akan meningkatkan minatnya untuk menjadikan profesi guru sebagai pilihan karir dimasa yang akan datang.

Minat mahasiswa terhadap profesi guru akan tumbuh dan terus menguat seiring berkembangnya ilmu pengetahuan dan pemahaman kependidikan yang dimilikinya. Hal ini berarti minat profesi guru ini harus muncul dari kesadaran, panggilan jiwa mahasiswa sebagai calon guru, dan berbagai faktor lainnya yang membentuk minat mahasiswa untuk menjadi guru (Sadirman, 2011). 


\section{KESIMPULAN}

Kesimpulan penelitian ini adalah mahasiswa kerjasama Pemerintah Provinsi Sumatera Selatan dengan Universitas Pendidikan Indonesia, masih banyak yang memiliki minat menjadi guru teknik. Faktor yang paling besar terhadap minat tersebut yaitu faktor keinginan diri sendiri tanpa paksaan. Faktor lain yang mempengaruhi yaitu lingkungan belajar dan beasiswa kemitraan, lingkungan tempat tinggal, dan posisi dan lingkungan dalam keluarga. Mahasiswa yang tidak berminat menjadi guru teknik, faktor penyebabnya adalah faktor keinginan diri sendiri tanpa paksaan dan beasiswa kemitraan, posisi dan lingkungan dalam keluarga dan lingkungan tempat tinggal, dan lingkungan belajar.

\section{DAFTAR PUSTAKA}

Rokhimah, S. (2015). Pengaruh Dukungan Sosial dan Efikasi Diri terhadap Minat Melanjutkan Pendidikan ke Perguruan Tinggi pada Siswa SMAN 1 Tenggarong Seberang. E-journal Psikologi. 3(1), hlm. 382-394.

Sadirman, A.M. (2011). Interaksi dan Motivasi Belajar Mengajar. Jakarta: PT Raja Grafindo Persada.

Sagala, S. (2011). Konsep dan Makna Pembelajaran. Bandung: Alfabeta.

Schiefele, U. (2005). Interest, Learning and Motivation. Educational Psycologist Journal. $26(3,4)$. pp.299-323.

Trianto. (2012). Mendesain Model Pembelajaran Inovatif-Progresif. Jakarta: Kencana Prenada Media Group.

Usman, M. U. (2005). Menjadi Guru Profesional. Bandung: PT. Remaja Rosdakarya. 